\title{
Analysis of restriction fragment length polymorphism for the HLA-DR gene in Japanese patients with sarcoidosis
}

Hiroshi Kunikane, Shosaku Abe, Etsuro Yamaguchi, Juan M R Aparicio, Akemi Wakisaka, Takashi Yoshiki, Yoshikazu Kawakami

\begin{abstract}
Background - It is commonly assumed that some immunological disorder may play a part in the pathogenesis of sarcoidosis. Previous studies by several groups have shown a significant association with HLA-DR antigens in patients with sarcoidosis. In this study, restriction fragment length polymorphism (RFLP) analysis of the HLA-DR gene was designed to confirm the association at the gene level and to look for a gene rearrangement which may influence susceptibility to sarcoidosis.

Methods - Thirty two unrelated Japanese patients with sarcoidosis were tested for HLA antigens and subjected to RFLP analysis after digestion with Eco RI, Pst I, Bam HI, Pvu II, and Hind III by using an HLA-DR $\beta$ cDNA probe. A group of 47 unrelated healthy Japanese subjects served as controls. Frequencies of each restriction fragment were compared between the patients and the control subjects. Correlation between fragment frequencies and clinical features were also analysed.
\end{abstract}

Results - No restriction fragments of HLA-DR $\beta$ gene were found specific to the patients with sarcoidosis. The RFLP analysis could detect polymorphism of HLADR $\beta$ genes that was not distinguishable by conventional serological methods. Several restriction fragments of the DR $\beta$ gene were seen only in DRw52 positive individuals, and showed higher frequencies in the patients than in control subjects. The patients with these DNA fragments were likely to have limited stage disease with no ophthalmic involvement. Conclusions - An association between HLA and sarcoidosis was noted at the DNA level, although no restriction fragments were specific for this disease. RFLP analysis of the HLA gene is a more useful method than the usual HLA typing, and should be the first step in identifying the gene sequence which is connected with susceptibility to sarcoidosis.

(Thorax 1994;49:573-576)

Sarcoidosis is a systemic granulomatous disease with frequent respiratory symptoms and changes on the chest radiograph. The pathogenesis of sarcoidosis remains unclear, but some studies suggest that it is an immunological disorder. In order to investigate the immunogenetic mechanisms the HLA system has frequently been examined.

We have previously found a significant association with HLA-DRw52 antigen in Japanese patients with sarcoidosis, ${ }^{1}$ the first such finding in any ethnic group. After our report associations with HLA-DRw8, as well as with DRw52, were also found in Japanese patients by others. ${ }^{2}$ In a German population an association between sarcoidosis and HLA-DR5 was reported. ${ }^{3}$ Findings from these three studies seemed to be similar because HLA-DRw52 is in strong linkage disequilibrium with DR5 and DRw8. ${ }^{4}$ It has not been possible, however, by conventional serological methods, to determine which HLA antigen plays the most important part in the pathogenesis of sarcoidosis.

Associations between HLA and many other diseases are currently being analysed with molecular biological techniques. HLA is highly polymorphic at the DNA level and restriction fragment length polymorphism (RFLP) analysis is performed to examine HLA gene polymorphism. HLA-D region antigen is a heterodimer composed of an $\alpha$ chain and a $\beta$-chain, ${ }^{5}$ and the HLA-DR genes consist of one $\mathrm{DR} \alpha$ gene and at least three $\mathrm{DR} \beta$ genes, ${ }^{6}$ named $\mathrm{DR} \beta_{1}, \mathrm{DR} \beta_{2}$, and $\mathrm{DR} \beta_{3}$. It is also known that 10 HLA-DR antigens named from DR1 to DRw10 are products of $\mathrm{DR} \alpha$ and $\mathrm{DR} \beta_{1}$ genes, and that DRw52 antigen is a product of $\mathrm{DR} \alpha$ and $\mathrm{DR} \beta_{3}$ genes. $^{7}$ $\mathrm{DR} \alpha$ gene is not polymorphic, ${ }^{5}$ so serological specificity of HLA-DR antigen is caused by polymorphism of DR $\beta$ genes.

In this study we performed RFLP analysis on 32 unrelated Japanese patients with sarcoidosis by using the HLA-DR $\beta$ cDNA probe and compared their fragment patterns with those of control subjects. DRw52 positive individuals whose serological specificities were identical showed different RFLP patterns, and there were different frequencies of several restriction fragments of the DR $\beta$ gene between the patients with sarcoidosis and the control subjects.

Methods

PATIENTS

A total of 32 consecutive patients (nine men, 23 women) with sarcoidosis diagnosed at the First Department of Medicine, Hokkaido University Hospital agreed to have their blood 
examined. Their ages ranged from 14 to 60 years, with an average of 37.8 years. All had abnormal radiographic features of either bilateral hilar lymphadenopathy or diffuse parenchymal lung changes. All had epithelioid granulomata characteristic of sarcoidosis which was histologically established by a biopsy of the lung, lymph node, or skin. The patients were divided into three groups on the basis of their chest radiographic findings ${ }^{1}$ and designated stages I, II, or III. Briefly, the patients with stage I disease had only radiological features of bilateral hilar lymphadenopathy, while those with stages II and III had both bilateral hilar lymphadenopathy and diffuse parenchymal changes or just parenchymal changes, respectively. A group of 47 unrelated healthy Japanese subjects served as the control group.

\section{HLA TYPING}

HLA typing was performed with the standard $\mathrm{NIH}$ complement dependent microcytotoxicity test; B lymphocytes were enriched by the thrombin nylon wool method, ${ }^{8}$ then incubated with antibodies at $37^{\circ} \mathrm{C}$ for one hour followed by a two hour incubation at $23^{\circ} \mathrm{C}$ with rabbit complement. The serum specimens or monoclonal antibodies used for HLA typing were well defined at the 10th International Histocompatibility Workshop (New York, 1987). Assignments of the HLA specificities were made on the Workshop nomenclature. ${ }^{9}$

\section{RFLP ANALYSIS}

Genomic DNA was extracted from peripheral blood nucleated cells by the method of Sambrook et al. ${ }^{10}$ After digestion with Eco RI, Pst I, Bam HI, Pvu II, or Hind III for 15 hours at $37^{\circ} \mathrm{C}, 10 \mu \mathrm{g}$ of digested DNA was electrophoresed on a $0.6 \%$ agarose gel at $25 \mathrm{~V}$ for 40 hours. After the electrophoresis the gels were alkaline denatured and transferred to nylon membranes by the method of Southern. ${ }^{11}$ The membrane was prehybridised overnight at $42^{\circ} \mathrm{C}$ and hybridised for 30 hours at $42^{\circ} \mathrm{C}$ with a DR $\beta$ cDNA probe labelled with $\left[\alpha-{ }^{32} \mathrm{P}\right]$ $\mathrm{dCTP}$ by the random primer method. The probe used was a Hind III/Sal I 786 base pair (bp) fragment of Caucasian HLA-DR $\beta$ cDNA provided in the 10th International Histocompatibility Workshop. ${ }^{12}$ This cDNA probe was derived from the $D R \beta_{3}$ gene. The filters were then washed four times after the hybridisation, twice with $2 \times$ saline-sodium phosphateEDTA (SSPE) [ $1 \times$ SSPE: $0.15 \mathrm{~mol} / 1 \mathrm{NaCl}$, $\left.10 \mathrm{mmol} / 1 \mathrm{NaH}_{2} \mathrm{PO}_{4}, 1 \mathrm{mmol} / 1 \mathrm{EDTA}\right]$ for five minutes at room temperature, once with a mixture of $2 \times$ SSPE and $0.5 \%$ SDS for 15 minutes at $65^{\circ} \mathrm{C}$, and once with a mixture of $0.5 \times \mathrm{SSPE}$ for 15 minutes at $65^{\circ} \mathrm{C}$. The filters were then exposed with intensifying paper to XAR-5 film (Eastman Kodak Co., Rochester, USA) for 20 hours at $-70^{\circ} \mathrm{C}$. Fragments with weak density which seemed to result from cross hybridisation were excluded from the frequency analysis.

\section{STATISTICAL ANALYSIS}

Both the antigen frequencies in HLA typing and the restriction fragment frequencies in the RFLP analysis in the patients with sarcoidosis and the control subjects were compared by the use of $2 \times 2$ tables. The $\chi^{2}$ test was used for statistical comparison.

\section{Results}

HLA ANTIGEN FREQUENCIES IN PATIENTS WITH SARCOIDOSIS

The frequencies of HLA-D region antigens in a group of 32 patients with sarcoidosis and 47 control subjects are given in table 1 . The frequency of HLA-DRw52 was $75.0 \%$ in the patient group and $51 \cdot 1 \%$ in the control group and this difference was statistically significant $\left(\chi^{2}=4.58, \mathrm{p}<0.05\right)$. Among HLA-A, B, C, and HLA-DQ antigens there was no antigen whose frequency showed a significant difference between the patients and the control subjects (data not shown for HLA-A, B, and C antigens).

\section{RFLP ANALYSIS FOR THE HLA-DR $\beta$ GENE}

RFLP analysis was performed in the 32 patients with sarcoidosis and the 47 control subjects. Restriction fragments of 24 DRw52 positive patients, hybridised with a DR $\beta$ probe after digestion with Eco RI, are shown in the figure. The RFLP analysis could detect polymorphism which was not distinguishable by usual HLA typing - for example, under digestion with Eco RI five DRw52 positive patients serologically typed as DR4 and DRw8 showed four different patterns of RFLP.

The frequencies of restriction fragments of the DR $\beta$ gene, after digestion with Eco RI, Pst I, Bam HI, Pvu II, and Hind III, are summarised in table 2 . Only restriction fragments whose frequencies were statistically different between the patients and the controls are shown. There were five DR $\beta$ fragments whose frequencies were higher in the patients than in the controls; Eco RI $10 \mathrm{~kb}$, Eco RI $4.6 \mathrm{~kb}$, Pst I $5.2 \mathrm{~kb}$, Bam HI $11 \mathrm{~kb}$, and Pvu II $9.5 \mathrm{~kb}$ fragments. All these were only seen in DRw52 positive individuals except for Pst I $5 \cdot 2 \mathrm{~kb}$

Table $1 H L A-D$ region antigen frequencies in patients with sarcoidosis

\begin{tabular}{lrrrrr}
\hline Antigen & \multicolumn{2}{c}{$\begin{array}{l}\text { Sarcoidosis patients } \\
(n=32)\end{array}$} & \multicolumn{2}{c}{$\begin{array}{l}\text { Control subjects } \\
(n=47)\end{array}$} \\
\cline { 2 - 3 } \cline { 5 - 6 } & $n$ & $\%$ & & $n$ & $\%$ \\
\hline DR1 & 1 & $3 \cdot 1$ & & 6 & $12 \cdot 8$ \\
DR2 & 10 & $31 \cdot 3$ & & 14 & $30 \cdot 0$ \\
DR3 & 0 & $0 \cdot 0$ & & 0 & $0 \cdot 0$ \\
DR4 & 13 & $40 \cdot 6$ & & 18 & $38 \cdot 3$ \\
DR5 & 7 & $21 \cdot 9$ & & 5 & $10 \cdot 6$ \\
DRw6 & 8 & $25 \cdot 0$ & & 11 & $23 \cdot 4$ \\
DR7 & 0 & $0 \cdot 0$ & & 1 & $2 \cdot 1$ \\
DRw8 & 11 & $34 \cdot 4$ & & 12 & $25 \cdot 5$ \\
DRw9 & 9 & $26 \cdot 1$ & & 19 & $40 \cdot 4$ \\
DRw10 & 0 & $0 \cdot 0$ & & 1 & $2 \cdot 1$ \\
DRw52 & 24 & $75 \cdot 0$ & & 24 & $51 \cdot 1$ \\
DRw53 & 20 & $62 \cdot 5$ & & 31 & $66 \cdot 0$ \\
DQw1 & 23 & $71 \cdot 9$ & & 31 & $66 \cdot 0$ \\
DQw2 & 0 & $0 \cdot 0$ & & 1 & $2 \cdot 1$ \\
DQw3 & 22 & $68 \cdot 8$ & & 33 & $70 \cdot 2$ \\
DQw4 & 6 & $18 \cdot 8$ & 12 & $25 \cdot 5$ \\
\hline
\end{tabular}

${ }^{1} \mathrm{p}<0.05$. 


\section{$122 \quad 3 \quad 4 \quad 5 \quad 6 \quad 7 \quad 8 \quad 9101112131415161718192021222324$}

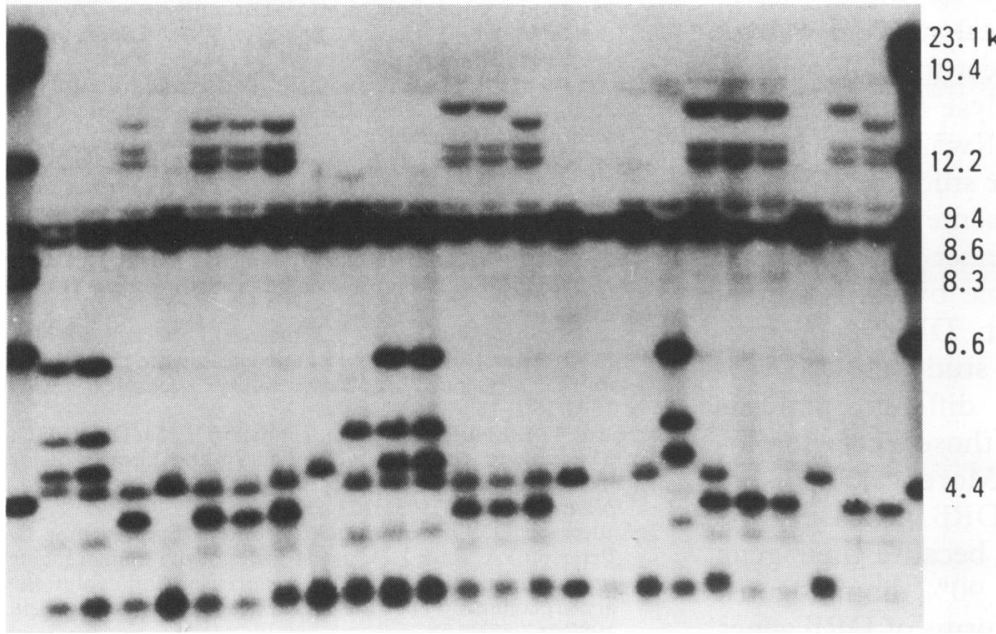

RFLP patterns of $24 D R w 52$ positive patients with sarcoidosis, hybridised with a $D R \beta$ probe after digestion with Eco RI. Serological DR specificity except for DRw52. Lane 1:DR2 and 5; lane 2:DR2 and 5; lane 3:DR4 and 5; lane 4:DR5 and w8; lane 5: DR5 and w9; lane 6:DR5 and w9; lane 7:DR5 and w9; lane 8:DRw6 and blank; lane 9: DR1 and w6; lane 10:DR2 and w6; lane 11: DR2 and w6; lane 12: DR4 and w6; lane 13:DR4 and w6; lane 14:DRw6 and w8; lane 15: DRw6 and w9; lane 16: DRw8 and blank; lane 17: DRw8 and blank; lane 18: DR2 and w8; lane 19: $D R 4$ and w8; lane 20:DR4 and w8; lane 21:DR4 and w8; lane 22:DR4 and w8; lane 23: DR4 and w8; lane 24: DRw8 and w9. Five patients (lane 19-23) serologically typed as DR4 and DRw8 showed four different patterns of RFLP.

which was found in one patient and one control subject, both of whom were DRw52 negative. Seventeen patients had all five fragments and 12 patients had none. There were three other patients who had one (Pst I $5 \cdot 2 \mathrm{~kb}$ ), three (Eco RI $10 \mathrm{~kb}$, Pst I $5 \cdot 2 \mathrm{~kb}$, Bam HI $11 \mathrm{~kb}$ ), and four (Eco RI $10 \mathrm{~kb}$, Eco RI $4.6 \mathrm{~kb}$, Pst I $5 \cdot 2 \mathrm{~kb}$, Bam HI $11 \mathrm{~kb}$ ) fragments. There was no restriction fragment whose frequency was higher in the controls than in the patients.

Table 2 Five restriction fragments of $H L A-D R \beta$ gene whose frequencies were higher in sarcoidosis patients than in control subjects

\begin{tabular}{|c|c|c|c|c|c|c|}
\hline & \multicolumn{3}{|c|}{ Sarcoidosis patients } & \multicolumn{3}{|c|}{ Control subjects } \\
\hline & $\begin{array}{l}\text { Total } \\
(n=32)\end{array}$ & $\begin{array}{l}D R w 52(+) \\
(n=24)\end{array}$ & $\begin{array}{l}\text { DRw52(-) } \\
(n=8)\end{array}$ & $\begin{array}{l}\text { Total } \\
(n=47)\end{array}$ & $\begin{array}{l}D R w 52(+) \\
(n=24)\end{array}$ & $\begin{array}{l}\text { DRw52(-) } \\
(n=23)\end{array}$ \\
\hline $\begin{array}{l}\text { Eco RI } 10 \mathrm{~kb} \\
\text { Eco RI } 4.6 \mathrm{~kb} \\
\text { Pst I } 5.2 \mathrm{~kb} \\
\text { Bam HI } 11 \mathrm{~kb} \\
\text { Pvu II } 9.5 \mathrm{~kb}\end{array}$ & $\begin{array}{l}19^{1} \\
18^{2} \\
20^{3} \\
19^{4} \\
17^{5}\end{array}$ & $\begin{array}{l}19 \\
18 \\
19 \\
19 \\
17\end{array}$ & $\begin{array}{l}0 \\
0 \\
1 \\
0 \\
0\end{array}$ & $\begin{array}{l}16^{1} \\
13^{2} \\
14^{3} \\
16^{4} \\
13^{5}\end{array}$ & $\begin{array}{l}16 \\
13 \\
13 \\
16 \\
13\end{array}$ & $\begin{array}{l}0 \\
0 \\
1 \\
0 \\
0\end{array}$ \\
\hline
\end{tabular}

$159.4 \%$ v $34.0 \%(\mathrm{p}<0.05)$

$256.3 \%$ v $27.7 \%(\mathrm{p}<0.05)$.

$56.3 \%$ v $27.7 \%(\mathrm{p}<0.05)$

${ }^{3} 62.5 \%$ v $29.8 \%(\mathrm{p}<0.01)$

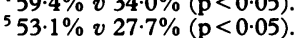

Table 3 Correlation between restriction fragments and clinical features or other organ involvement

\begin{tabular}{|c|c|c|c|}
\hline & $\begin{array}{l}\text { Group } 1 \\
(n=19)\end{array}$ & $\begin{array}{l}\text { Group } 2 \\
(n=13)\end{array}$ & $\begin{array}{l}\text { Total } \\
(n=32)\end{array}$ \\
\hline $\begin{array}{l}\text { Sex } \\
\text { Male } \\
\text { Female }\end{array}$ & $\begin{array}{r}5(26 \cdot 3 \%) \\
14(73 \cdot 7 \%)\end{array}$ & $\begin{array}{l}4(30 \cdot 8 \%) \\
9(69 \cdot 2 \%)\end{array}$ & $\begin{array}{r}9(28.1 \%) \\
23(71.9 \%)\end{array}$ \\
\hline Mean age at onset (years) & $34 \cdot 3$ & $42 \cdot 8$ & $37 \cdot 8$ \\
\hline $\begin{array}{l}\text { Clinical stage } \\
\text { I } \\
\text { II } \\
\text { III }\end{array}$ & $\begin{array}{c}16(84 \cdot 2 \%)^{1} \\
2(10 \cdot 5 \%) \\
1(5 \cdot 3 \%)\end{array}$ & $\begin{array}{l}6(46 \cdot 2 \%)^{1} \\
6(46 \cdot 2 \%) \\
1(7 \cdot 7 \%)\end{array}$ & $\begin{array}{c}22(68.8 \%) \\
8(25 \cdot 0 \%) \\
2(6.3 \%)\end{array}$ \\
\hline $\begin{array}{l}\text { Other organ involvement } \\
\text { Eyes (+) } \\
(-) \\
\text { Skin }(+) \\
(-) \\
\text { Liver (+) } \\
(-)\end{array}$ & $\begin{array}{c}6(31 \cdot 6 \%)^{2} \\
13(68 \cdot 4 \%) \\
1(5 \cdot 3 \%) \\
18(94 \cdot 7 \%) \\
1(5 \cdot 3 \%) \\
18(94 \cdot 7 \%)\end{array}$ & $\begin{array}{l}9(69 \cdot 2 \%)^{2} \\
4(30 \cdot 8 \%) \\
4(30 \cdot 8 \%) \\
9(69 \cdot 2 \%) \\
1(7 \cdot 7 \%) \\
12(92 \cdot 3 \%)\end{array}$ & $\begin{array}{c}15(46.9 \%) \\
17(53 \cdot 1 \%) \\
5(15 \cdot 6 \%) \\
27(84 \cdot 4 \%) \\
2(6.3 \%) \\
30(93 \cdot 8 \%)\end{array}$ \\
\hline
\end{tabular}

${ }^{1} \mathrm{p}<0.05 ;{ }^{2} \mathrm{p}<0.05$
CORRELATION BETWEEN RESTRICTION

FRAGMENTS AND CLINICAL FEATURES OR OTHER ORGAN INVOLVEMENT

In order to analyse whether there were different clinical features between the patients with and without the five restriction fragments the patients were divided into two groups according to the presence of the fragments. Group 1 consisted of patients who had three or more of the five fragments and group 2 consisted of patients with up to two fragments. The correlation between groups 1 and 2 and various clinical features or other organ involvement is summarised in table 3. There were more patients in group 1 than in group 2 whose clinical stage was limited to stage I $(p<0.05)$. With regard to involvement of other organs, there were more patients in group 1 than in group 2 without an ophthalmic disorder $(p<0.05)$.

\section{Discussion}

HLA is an excellent marker for investigating genetic factors in many diseases. HLA antigens are divided into two groups; HLA-A, B, $C$ (class I) antigens and HLA-D region (class II) antigens. ${ }^{1314}$ Since human immune response and immune suppression genes exist in HLA-D region, ${ }^{1516}$ and HLA-D region antigens are connected with the susceptibility of some diseases, more studies have to be performed to analyse class II antigens. With regard to the association between sarcoidosis and HLA antigens, some interesting results were found on HLA-D region antigens whereas no clear conclusions have been obtained on HLA$A, B$, and C. ${ }^{1718}$

HLA-D region antigens are composed of at least three different groups of antigen molecules - DR, DQ, and DP antigens ${ }^{19}-$ but an association with sarcoidosis has so far been reported only with DR antigens. The HLADR antigens in which an association with sarcoidosis has been reported are DRw52, ${ }^{12}$ DRw8, ${ }^{2}$ and DRw9 ${ }^{2}$ in Japanese subjects, DR5 in Germans, ${ }^{3}$ and DR7 in West Indians. ${ }^{20}$ Among these antigens an association with DRw52, DR5, or DRw8 which was reported by three groups including ours is reproducible and the most interesting because DRw52 is in strong linkage disequilibrium with DR5 and DRw8. In this study frequencies of most HLA-DR antigens were similar to those found in our previous study. ${ }^{1}$ The largest difference was observed in the frequency of DRw53 in the patients between the two studies, but this difference was not statistically significant. The association with DRw52, which we previously reported, was also observed in the present study. It should be concluded that DRw52 antigen occurs in $70-80 \%$ of Japanese patients with sarcoidosis, but only in $50-55 \%$ of healthy controls. It was also noted that DR5 and DRw8 antigens were more common in patients with sarcoidosis than in controls, but an association with DRw9 was not observed. DR7 is a very rare antigen in the Japanese population ${ }^{21}$ and there were no patients with DR7 in this study. 
DRw52 antigen was reported to have polymorphism by a biochemical method. ${ }^{22}$ It is therefore important to detect the polymorphism of DRw52 and to analyse the association between sarcoidosis and DRw52 more closely. RFLP analysis is useful for studying the association between HLA and some diseases at the gene level because it can detect polymorphism which is not distinguishable by conventional serological typing. In fact, DRw52 positive individuals in the present study showed various RFLP patterns and different patterns were observed even among those whose serological types were identical. Moreover, by using a single DR $\beta$ probe all DR $\beta$ genes can be analysed at the same time because their gene sequences are more than $90 \%$ homologous. There are different allelic forms of DR $\beta$ genes and many individuals are heterozygous for them. RFLP analysis of the HLA gene is a more useful method for studying immunogenetic mechanisms of many diseases than usual HLA typing.

One of the purposes of this study was to determine whether there was any restriction fragment of the HLA-DR $\beta$ gene specific to patients with sarcoidosis, but such a fragment was not found. DNA sequence analysis will be necessary to determine whether sarcoidosis patients have any special HLA-DR gene, but so far such a specific gene has not been reported in any disease. There may be many genetic factors in the pathogenesis of sarcoidosis and it is possible that HLA is only one of them.

We also wanted to find out why there are some patients with sarcoidosis who do not have the DRw52 antigen. We speculated that there is heterogeneity in sarcoidosis and that the DRw52 antigen plays a part in only some patients. It is possible that clinical features may differ depending on whether the HLA antigen has a role. We have previously noted that the association with DRw52 was stronger in patients with sarcoidosis without ophthalmic involvement ${ }^{1}$ and the five restriction fragments identified this subgroup of DRw52 positive individuals. There may be a subgroup of patients with sarcoidosis who remain in the limited stage and are unlikely to have involvement of other organs, especially the eyes.

The authors thank Erick D Schwab for his help in the preparation of the manuscript.
1 Kunikane $\mathrm{H}$, Abe S, Tsuneta $\mathrm{Y}$, Nakayama T, Tajima $\mathrm{Y}$, Misonou J, et al. Role of HLA-DR antigens in Japanese Misonou J, et al. Role of HLA-DR antigens in Japanese
patients with sarcoidosis. Am Rev Respir Dis patients with $1987 ; 135: 688-91$.

2 Ina Y, Takada $\mathrm{K}$, Yamamoto $\mathrm{M}$, Morishita $\mathrm{M}$, Asai $\mathrm{M}$, Arakawa K, et al. HLA and sarcoidosis in Japanese. $\mathcal{f} p n \mathcal{F}$ Thorac Dis 1988;28:984-8.

3 Nowack D, Goebel KM. Genetic aspects of sarcoidosis Class II histocompatibility antigens and a family study. Arch Intern Med 1987;147:481-3.

4 Conighi C, Mattiuz PL, Schreuder GMT. Antigen report: HLA-DRw52. In: Albert ED, Baur MP, Mayr WR, eds. Histocompatibility testing 1984. Berlin: Springer-Verlag, 1984:202-3.

5 Kaufman JK, Auffray C, Korman AJ, Shackelford DA, Strominger J. The class II molecules of the human and murine major histocompatibility complex. Cell 1984;36:1-13.

6 Hardy DA, Bell JI, Long EO, Lindstern T, McDevitt HO. Mapping of the class II region of the human major histocompatibility complex by pulsed-field gel electrophoresis. Nature 1986;323:453-5.

7 Andersson G, Larhammar D, Widmark E, Servenius B, Peterson PA, Rask L. Class II genes of the human major histocompatibility complex. Organization and evolutionhistocompatibility complex. Organization and evolutionary relationship

8 Danilovs JA, Ayoub G, Terasaki PI. B lymphocyte isolation by thrombin-nylon wool. In: Terasaki PI, ed. Histocompatibility testing 1980. Los Angeles: UCLA Tissue Typing Laboratory, 1980:287-8.

9 Bodmer WF, Albert E, Bodmer JG, Dupont B, March B, Mayr WR, et al. Nomenclature for factors of the HLA system, 1987. In: Dupont B, ed. Immunobiology of HLA. New York: Springer-Verlag, 1989:72-9.

10 Sambrook J, Fritsch EF, Maniatis T. Isolation of highmolecular-weight DNA from mammalian cells. In: Ford N, Ed. Molecular cloning. 2nd ed. New York: Cold Spring Harbor Laboratory Press, 1989;9.14-9.23.

11 Southern EM. Detection of specific sequences among DNA fragments separated by gel electrophoresis. $7 \mathrm{Mol}$ Biol 1975;98:503-17.

12 Long EO, Wake CT, Gorski J, Mach B. Complete sequence of an HLA-DR $\beta$ chain deduced from a cDNA clone and identification of multiple non-allelic DR $\beta$ chain gene. Embo f 1983;2:389-94.

13 Bell JI, Denny Jr. DW, McDevitt HO. Structure and polymorphism of murine and human class II major histopolymorphism of murine and human class II major his

14 Srivastava R, Duceman BW, Biro PA, Sood AK, Weissman SM. Molecular organization of the class I genes of human major histocompatibility complex. Immunol Rev 1985; 84:93-121.

15 Greenberg LJ, Bradley PW, Chopyk RL, Lalovel JM. Immunogenetics of response to a purified antigen from group A streptococci. II. Linkage of response to HLA. Immunogenetics 1980;11:161-7.

16 Sasazuki T, Kaneoka H, Nishimura Y, Kaneoka R, Hamaya $\mathrm{M}$, Ohkuni H. An HLA-linked immune suppression gene in man. $f$ Exp Med 1980;152:Suppl.297-313.

17 Olenchock SA, Heise ER, Marx Jr JJ, Mentnech MS, Mull JC, Spurgeon DE, et al. HLA-B8 in sarcoidosis. Ann Allergy 1981;47:151-3.

18 Kueppers F, Mueller-Eckhardt $\mathrm{CH}$, Heinrich D, Schwab B, Brackertz D. HL-A antigens of patients with sarcoidosis. Tissue Antigens 1974;4:56-8.

19 Albert ED, Baur MP, Mayr WR. Nomenclature for factors of the HLA system 1984. In Albert ED, Baur MP, Mayr WR, eds. Histocompatibility testing 1984. Berlin: Springer-Verlag, 1984:4-8.

20 Gardner J, Kennedy HG, Hamblin A, Jones E. HLA associations in sarcoidosis: a study of two ethnic groups. Thorations in sarcoido $1984 ; 39: 19-22$.

21 Albert E. Joint report: DR7. In: Terasaki PI, ed. Histocompatibility testing 1980. Los Angeles: UCLA Tissue Typing Laboratory, 1980:535-7.

22 Fuggle SV, Carter C, Watts F, Kirkley J, Morris PJ. Monoclonal antibody definition of multiple polymorphic epitopes on human leukocyte antigen-DRw52. Hum Immunol 1987;20:249-64. 